\title{
Direct Involvement of Orexinergic Systems in the Activation of the Mesolimbic Dopamine Pathway and Related Behaviors Induced by Morphine
}

\author{
Minoru Narita, ${ }^{1}$ Yasuyuki Nagumo, ${ }^{1}$ Seiko Hashimoto, ${ }^{1}$ Michiko Narita, ${ }^{1}$ Junaidi Khotib, ${ }^{1}$ Mayumi Miyatake, ${ }^{1}$ \\ Takeshi Sakurai, ${ }^{2}$ Masashi Yanagisawa, ${ }^{3}$ Tomoya Nakamachi, ${ }^{4}$ Seiji Shioda, ${ }^{4}$ and Tsutomu Suzuki ${ }^{1}$ \\ ${ }^{1}$ Department of Toxicology, Hoshi University School of Pharmacy and Pharmaceutical Sciences, Shinagawa-ku, Tokyo 142-8501, Japan, ${ }^{2}$ Institute of Basic \\ Medical Sciences, University of Tsukuba, Tsukuba, Ibaraki 305-8575, Japan, ${ }^{3}$ Department of Molecular Genetics and Howard Hughes Medical Institute, \\ University of Texas Southwestern Medical Center, Dallas, Texas 75390-9050, and ${ }^{4}$ Department of Anatomy, Showa University School of Medicine, \\ Shinagawa-ku, Tokyo 142-8555, Japan
}

In this study, we investigated the role of orexinergic systems in dopamine-related behaviors induced by the $\mu$-opioid receptor agonist morphine in rodents. Extensive coexpression of tyrosine hydroxylase with orexin receptors was observed in the mouse ventral tegmental area (VTA). The levels of dopamine and its major metabolites in the nucleus accumbens were markedly increased by the microinjection of orexin A and orexin B into the VTA. The subcutaneous morphine-induced place preference and hyperlocomotion observed in wild-type mice were abolished in mice that lacked the prepro-orexin gene. An intra-VTA injection of a selective orexin receptor antagonist SB334867A [1-(2-methylbenzoxazol-6-yl)-3-[1.5]naphthyridin-4-yl urea] significantly suppressed the morphine-induced place preference in rats. Furthermore, the increased level of dialysate dopamine produced by morphine in the mouse brain was significantly decreased by deletion of the prepro-orexin gene. These findings provide new evidence that orexin-containing neurons in the VTA are directly implicated in the rewarding effect and hyperlocomotion induced by morphine through activation of the mesolimbic dopamine pathway in rodents.

Key words: orexin; opioid; morphine; reward; addiction; dependence

\section{Introduction}

Recently, several neuropeptides have been shown to be highly enriched in the lateral hypothalamus (LH). Orexins (also known as hypocretins) are a family of hypothalamic neuropeptides that are selectively expressed in the LH (de Lecea et al., 1998; Sakurai et al., 1998). The orexins (orexin A and orexin B) arise from the precursor peptide prepro-orexin by proteolytic processing and are expressed in high density in LH neurons (de Lecea et al., 1998; Sakurai et al., 1998). Orexins bind and activate two closely related G-protein-coupled receptors, orexin 1 receptor (OX1R) and orexin 2 receptor (OX2R) (Sakurai et al., 1998). It is generally accepted that activation of these receptors by the central administration of orexin elicits feeding (Hagan et al., 1999).

Brain dopamine systems have been the focus of histochemical, biochemical, and pharmacological research into the rewarding effects and locomotor activity induced by opioids and psycho-

Received June 24, 2004; revised Nov. 9, 2005; accepted Nov. 11, 2005.

This work was supported by a Research Grant from the Ministry of Education, Culture, Sports, Science, and Technology of Japan. We thank Dr. Keisuke Mizuo, Daigo Ikegami, Keiichi Niikura, Keiko Shindo, Hiroko Sugitani, and Akiko Kasukawa for their expert technical assistance.

Correspondence should be addressed to either Dr. Minoru Narita or Dr. Tsutomu Suzuki, Department of Toxicology, Hoshi University School of Pharmacy and Pharmaceutical Sciences, 2-4-41 Ebara, Shinagawa-ku, Tokyo 1428501, Japan.E-mail: narita@hoshi.ac.jp and suzuki@hoshi.ac.jp.

DOI:10.1523/JNEUROSCI.2761-05.2006

Copyright $\odot 2006$ Society for Neuroscience $\quad$ 0270-6474/06/260398-08\$15.00/0 stimulants. The ascending anatomical dopamine projection from the ventral tegmental area (VTA) to the nucleus accumbens (NAcc) and prefrontal cortex consists of mesolimbic (A10) dopamine neurons (Wise and Rompre, 1989; Koob, 1992). The activation of mesolimbic dopamine neurons occurs in association with natural environmental stimuli, including food (Wilson et al., 1995; Berridge, 1996; Berridge and Robinson, 1998). Mesolimbic dopamine neurons are also involved in brain mechanisms of reward, reinforcement, and emotion (Wise and Rompre, 1989).

Orexin-containing neurons project widely to numerous brain regions, including the cortex, thalamus, brainstem, and spinal cord (Peyron et al., 1998; Date et al., 1999; van den Pol, 1999). This diffuse pattern of efferent fibers suggests that the orexinergic system may play a role in the regulation of multiple brain functions, including emotions. The VTA and NAcc receive massive input from the $\mathrm{LH}$ area, including projections from neurons containing orexin A and orexin B (Fadel and Deutch, 2002). In addition, it has recently been proposed using electrophysiological methods that orexins directly activate VTA dopamine neurons (Korotkova et al., 2003). These data suggest a functional interplay between orexin and mesolimbic dopamine neurons. It is of interest to note that morphine-induced physical dependence and withdrawal have been shown to be, at least in part, regulated by orexin neurons (Georgescu et al., 2003). However, little, if any, is 
known about the functional and/or direct interaction between the orexinergic system and opioid-related rewarding effects. The aim of the present study was to assess whether the prototypical $\mu$-opioid receptor agonist morphine could produce rewarding effects and hyperlocomotion in the prepro-orexin knock-out mice and deletion of prepro-orexin gene could affect the morphine-induced dopamine increase in the NAcc We also determined whether orexin-containing neurons, which terminate to the VTA, could participate in the activation of the mesolimbic dopamine neuron by morphine using the microinjection method.

\section{Materials and Methods}

The present study was conducted in accordance with the Guiding Principles for the Care and Use of Laboratory Animals (Hoshi University), as adopted by the Committee on Animal Research of Hoshi University, which is accredited by the Ministry of Education, Culture, Sports, Science, and Technology of Japan. Every effort was made to minimize the number and suffering of animals used in the following experiments.

Animals. In the present study, we used prepro-orexin knock-out mice (male and female), their wild-type C57BL/6J mice, ICR mice, and male Sprague Dawley rats (Tokyo Laboratory Animals Science, Tokyo, Japan). Prepro-orexin knock-out mice with a genetic background of a mixture of 129/Sv and C57BL/6J were generated as reported previously (Chemelli et al., 1999). Animals were housed in a room maintained at $23 \pm 1^{\circ} \mathrm{C}$ with a $12 \mathrm{~h}$ light/dark cycle (lights on 8:00 A.M. to 8:00 P.M.). Food and water were available ad libitum.

Surgery and microinjection. After $3 \mathrm{~d}$ of habituation to the main animal colony, all rats were anesthetized with sodium pentobarbital $(50 \mathrm{mg} / \mathrm{kg}$, i.p.). The anesthetized animals were placed in a stereotaxic apparatus. The skull was exposed, and a small hole was made using a dental drill. A guide cannula (AG-9 or AG-8; Eicom, Kyoto, Japan) was implanted into the VTA (from bregma: posterior, $-5.3 \mathrm{~mm}$; lateral, $-0.9 \mathrm{~mm}$; ventral, $-7.7 \mathrm{~mm}$ ), NAcc (from bregma: anterior, $+4.0 \mathrm{~mm}$; lateral, $-0.8 \mathrm{~mm}$; ventral, $-6.8 \mathrm{~mm}$; angle $16^{\circ}$ ) or substance nigra (SN) (from bregma: posterior, $-5.3 \mathrm{~mm}$; lateral, $-2.2 \mathrm{~mm}$; ventral, $-7.8 \mathrm{~mm}$ ) according to the atlas of Paxinos and Watson (1998). The guide cannula was fixed to the skull with cranioplastic cement. Three to $5 \mathrm{~d}$ after surgery, the animals were injected with the selective orexin receptor antagonist 1-(2methylbenzoxazol-6-yl)-3-[1.5]naphthyridin-4-yl urea (SB334867A) (Tocris Bioscience, Ellisville, MO) into the VTA $10 \mathrm{~min}$ before the start of conditioning with morphine. In the microinjection method, we used the injection cannula (AMI-9.5; Eicom) extended beyond the guide cannula by $0.5 \mathrm{~mm}$. A stainless steel injection cannula was inserted into that guide cannula for each animal. The injection cannula was connected through polyethylene tubing to a $10 \mu \mathrm{l}$ Hamilton syringe that was preloaded with SB334867A $(0.1,1$, or $10 \mathrm{nmol} / 0.3 \mu \mathrm{l})$ or vehicle. The receptor antagonist or vehicle was delivered by motorized syringe pump in a volume of $0.3 \mu$ lover $60 \mathrm{~s}$.

Place conditioning. Place conditioning was conducted as described previously (Suzuki et al., 1990). The apparatus was a shuttle box (mouse size, $15 \mathrm{~cm}$ wide $\times 30 \mathrm{~cm}$ long $\times 15 \mathrm{~cm}$ high; rat size, $30 \mathrm{~cm}$ wide $\times 60 \mathrm{~cm}$ long $\times 30 \mathrm{~cm}$ high) that was made of acrylic resin board and divided into two equal-sized compartments. One compartment was white with a textured floor, and the other was black with a smooth floor to create equally preferable compartments. The place conditioning schedule consisted of three phases (preconditioning test, conditioning, and postconditioning test). The preconditioning test was performed as follows: the partition separating the two compartments was raised to $7 \mathrm{~cm}$ (mouse) or $12 \mathrm{~cm}$ (rat) above the floor, a neutral platform was inserted along the seam separating the compartments, and animals that had not been treated with either drugs or saline were then placed on the platform. The time spent in each compartment during a $900 \mathrm{~s}$ session was then recorded automatically with an infrared beam sensor (KN-80; Natsume Seisakusyo, Tokyo, Japan). Conditioning sessions ( $3 \mathrm{~d}$ for morphine, $3 \mathrm{~d}$ for saline) were conducted once daily for $6 \mathrm{~d}$. Immediately after morphine injection, these animals were placed in the compartment opposite that in which they had spent the most time in the preconditioning test for $1 \mathrm{~h}$. On alternative days, these animals received saline and were placed in the other compartment for $1 \mathrm{~h}$. On the day after the final conditioning session, a postconditioning test that was identical to the preconditioning test was performed. The selective orexin receptor antagonist SB334867A (Tocris Bioscience) was injected into the VTA 10 min before the start of conditioning with morphine.

Locomotor assay. The locomotor activity of mice was measured by an ambulometer as described previously (Narita et al., 1993, 2002). Briefly, a mouse was placed in a tilting-type round activity cage $20 \mathrm{~cm}$ in diameter and $19 \mathrm{~cm}$ high. Any slight tilt of the activity cage, which was caused by horizontal movement of the mouse, was detected by three microswitches. Counts of hyperlocomotor activity were collected in $10 \mathrm{~min}$ intervals for $180 \mathrm{~min}$ after morphine and for $120 \mathrm{~min}$ after orexin A or orexin B. In the combination study, haloperidol $(0.1 \mathrm{mg} / \mathrm{kg})$ was administered subcutaneously $30 \mathrm{~min}$ before intracerebroventricular treatment with orexins. To destroy central dopaminergic neurons, mice were treated with an intracerebroventricular $150 \mathrm{nmol}$ dose of 6-OHDA $72 \mathrm{~h}$ before intracerebroventricular-administered orexins. Additionally, desipramine $(25 \mathrm{mg} / \mathrm{kg}$, s.c.) was given to mice $10 \mathrm{~min}$ before 6-OHDA (intracerebroventricularly) to block the uptake of 6-OHDA into noradrenergic terminals (Alhaider, 1991).

$R N A$ preparation and semiquantitative analysis by reverse transcription$P C R$. Total RNA in the whole brain (except cerebellum) was extracted using the SV Total RNA Isolation System (Promega, Madison, WI) following the instructions of the manufacturer. First-strand cDNA was prepared as described previously (Narita et al., 2001b), and the preproorexin gene was amplified in $50 \mu \mathrm{l}$ of a PCR solution containing $0.2 \mathrm{mM}$ dNTP mix (Invitrogen, Carlsbad, CA), 0.5 m GC Melt, 0.1× GC 2 PCR Buffer, and $1 \times$ Advantage GC 2 Polymerase Mix (BD Advantage-GC 2 PCR kit; BD Biosciences Clontech, Palo Alto, CA) with synthesized primers of either prepro-orexin (294 bp) (sense, $5^{\prime}$-CAG CCT CTG CCC GAC TGC TGT CGC CAG AAG-3'; antisense, 5' -GAC TCC GGA CCC TCC CCG GGG TGC TAA AGC-3') or prepro-orexin (270 bp) (sense, 5'-CAG CCT CTG CCC GAC TGC TGT C-3'; antisense, 5' -TAA AGC GGT GGT AGT TAC GGT CGG AC- $3^{\prime}$ ). Samples were heated to $94^{\circ} \mathrm{C}$ for $5 \mathrm{~min}, 55^{\circ} \mathrm{C}$ for $1 \mathrm{~min}$, and $72^{\circ} \mathrm{C}$ for $1 \mathrm{~min}$, and cycled 35 times through $94^{\circ} \mathrm{C}$ for $30 \mathrm{~s}, 55^{\circ} \mathrm{C}$ for $1 \mathrm{~min}$, and $72^{\circ} \mathrm{C}$ for $1 \mathrm{~min}$. The final incubation was at $72^{\circ} \mathrm{C}$ for $7 \mathrm{~min}$. The mixture was subjected to $2 \%$ agarose gel electrophoresis with the indicated markers and primers for the internal standard glyceraldehyde-3-phosphate dehydrogenase. Each sample was applied to more than two lanes in the same gel. The agarose gel was stained with ethidium bromide and photographed with ultraviolet transillumination. The intensity of the bands was analyzed and quantified by computer-assisted densitometry using NIH Image software.

Immunohistochemical approach. Mice were deeply anesthetized with sodium pentobarbital (70 mg/kg, i.p.) and perfusion fixed with $4 \%$ paraformaldehyde, $\mathrm{pH}$ 7.4. The brains were then quickly removed after perfusion, and thick coronal sections of the midbrain including the VTA were initially dissected using Brain Blocker. The brain coronal sections were postfixed in $4 \%$ paraformaldehyde for $2 \mathrm{~h}$. After the brains were permeated with $20 \%$ sucrose for $1 \mathrm{~d}$ and $30 \%$ sucrose for $2 \mathrm{~d}$, they were frozen in embedding compound (Sakura Finetechnical, Tokyo, Japan) on isopentane using liquid nitrogen and stored at $-30^{\circ} \mathrm{C}$ until use. Frozen 8 - $\mu$ m-thick coronal sections were cut with a cryostat (CM1510; Leica, Heidelberg, Germany) and thaw mounted on poly-L-lysine-coated glass slides. The brain sections were blocked in $10 \%$ normal horse serum (NHS) in $0.01 \mathrm{~m}$ PBS for $1 \mathrm{~h}$ at room temperature. Each primary antibody was diluted in $0.01 \mathrm{~m}$ PBS containing 10\% NHS [1:20 tyrosine hydroxylase (TH) (Chemicon, Temecula, CA), 1:1000 OX1R (Chemicon), and 1:1000 OX2R (Alpha Diagnostic International, San Antonio, TX)] and incubated for $2 \mathrm{~d}$ at $4^{\circ} \mathrm{C}$. The samples were then rinsed and incubated with the appropriate secondary antibody conjugated with Alexa 488 and Alexa 546 for $2 \mathrm{~h}$ at room temperature. The slides were then coverslipped with PermaFluor Aqueous mounting medium (Immunon, Pittsburgh, PA). Fluorescence immunolabeling was detected using a light microscope (AX-70; Olympus Optical, Tokyo, Japan) and photographed with a digital camera (Polaroid PDMCII/OL; Olympus Optical).

Rat in vivo microdialysis study and quantification of dopamine. Three to $5 \mathrm{~d}$ after the surgery, microdialysis probes (AI-8-2; $2 \mathrm{~mm}$ membrane length; Eicom) were slowly inserted into the nucleus accumbens through 
guide cannulas under anesthesia with diethyl ether, and rats were settled in the experimental cages ( $30 \mathrm{~cm}$ wide $\times 30 \mathrm{~cm}$ deep $\times 30 \mathrm{~cm}$ high). The probes were perfused continuously at a flow rate of $2 \mu \mathrm{l} / \mathrm{min}$ with artificial CSF (aCSF) containing $0.9 \mathrm{~mm} \mathrm{MgCl}_{2}, 147.0 \mathrm{~mm} \mathrm{NaCl}, 4.0 \mathrm{~mm} \mathrm{KCl}$, and $1.2 \mathrm{mM} \mathrm{CaCl}_{2}$. The outflow fractions were taken every $20 \mathrm{~min}$. After the collection of three baseline fractions in the rat NAcc, orexin A, orexin $\mathrm{B}$, or saline was treated into the rat VTA using a $10 \mu \mathrm{l}$ Hamilton syringe and motorized syringe pump. For these experiments, dialysis samples were collected for the next $180 \mathrm{~min}$ after orexin A or orexin B treatment. Dialysis fractions were then analyzed using HPLC (Eicom) with electrochemical detection (ECD) (Eicom) system. Dopamine was separated by a column with mobile phase containing sodium acetate $(4.05 \mathrm{~g} / \mathrm{L})$, citric acid monohydrate $(7.35 \mathrm{~g} / \mathrm{L})$, sodium 1-octane sulfonate $(170 \mathrm{mg} / \mathrm{L})$, EDTA $(2 \mathrm{Na} ; 10 \mathrm{mg} / \mathrm{L})$, and $17 \%$ methanol. The mobile phase was delivered at a flow rate of $210 \mu \mathrm{l} / \mathrm{min}$. Identification of dopamine was determined according to the retention times of dopamine standard, and amounts of dopamine were quantified by calculating with peak areas.

Mouse in vivo microdialysis study and quantification of dopamine. Stereotaxic surgery was performed under sodium pentobarbital $(70 \mathrm{mg} / \mathrm{kg}$, i.p.) anesthesia. Mice were placed in a stereotaxic apparatus, and the skull was exposed. A small hole was then made using a dental drill. A microdialysis probe (D-I-6-01; $1 \mathrm{~mm}$ membrane length; Eicom) was implanted into the NAcc (from bregma: anterior, $+1.5 \mathrm{~mm}$; lateral, $-0.9 \mathrm{~mm}$; ventral, $-4.9 \mathrm{~mm}$ ) according to the atlas of Paxinos and Franklin (1997). The microdialysis probe was fixed to the skull with cranioplastic cement. At $24 \mathrm{~h}$ after implantation, mice were placed in the experimental cages (30 $\mathrm{cm}$ wide $\times 30 \mathrm{~cm}$ long $\times 30 \mathrm{~cm}$ high). The probe was perfused continuously at a flow rate of $2 \mu \mathrm{l} / \mathrm{min}$ with aCSF containing $0.9 \mathrm{~mm}$ $\mathrm{MgCl}_{2}, 147.0 \mathrm{~mm} \mathrm{NaCl}, 4.0 \mathrm{~mm} \mathrm{KCl}$, and $1.2 \mathrm{~mm} \mathrm{CaCl}_{2}$. Outflow fractions were taken every $5 \mathrm{~min}$. After 15 baseline fractions were collected, mice were given morphine $(10 \mathrm{mg} / \mathrm{kg}$, s.c.) or saline $(1 \mathrm{ml} / \mathrm{kg}$, s.c.). For this experiment, dialysis samples were collected for 180 min after morphine or saline treatment. Dialysis fractions were then analyzed using HPLC with ECD (HTEC-500; Eicom). Dopamine was separated by a column with a mobile phase containing $0.1 \mathrm{M} \mathrm{NaH}_{2} \mathrm{PO}_{4}, 0.1 \mathrm{M} \mathrm{Na}_{2} \mathrm{HPO}_{4}$, $2.0 \mathrm{~mm}$ sodium 1 -decane sulfonate, $0.1 \mathrm{~mm}$ EDTA $(2 \mathrm{Na})$, and $1 \%$ methanol. The mobile phase was delivered at a flow rate of $550 \mu \mathrm{l} / \mathrm{min}$. Dopamine was identified according to the retention times of a dopamine standard, and amounts of dopamine were quantified by calculating with peak areas. The baseline microdialysis data were calculated as concentrations in the dialysates. Other microdialysis data are expressed as percentages of the corresponding baseline level.

Drugs and injection procedure. The drugs used in the present study were morphine hydrochloride (Sankyo, Tokyo, Japan), orexin A, orexin B, 6-OHDA hydrochloride, desipramine hydrochloride, haloperidol, lithium chloride (Sigma-Aldrich, St. Louis, MO), and the selective orexin receptor antagonist SB334867A (Tocris Bioscience). Intracerebroventricular administration was performed according to the method described previously (Haley and McCormick, 1957). To make a hole in the skull for injection, 2-3 d before locomotor assay, mice were briefly anesthetized with ether, and a $2 \mathrm{~mm}$ double needle (Natsume Seisakusho) attached to a $25 \mu \mathrm{l}$ Hamilton microsyringe was inserted into the unilateral injection site using a $\mathrm{V}$-shaped holder to hold the head of the mouse. On the day of the locomotor assay, orexin A or orexin B (each 5 and 10 $\mathrm{nmol} /$ mouse) was injected into the hole. The injection volume was $4 \mu \mathrm{l}$ for each mouse.

Histology. Determination of the location of the infusion cannula placements and drug diffusion was assessed at the completion of the experiments. Rats were deeply anesthetized with sodium pentobarbital (50 $\mathrm{mg} / \mathrm{kg}$ ) at the end of the experiment and given microinjections of ink for anatomical localization of cannula sites $(0.3 \mu \mathrm{l})$. The brain was then removed by decapitation and cut into coronal sections. Cannula placements were mapped onto a stereotaxic atlas (Paxinos and Watson, 1998) and confirmed to be in the VTA.

Statistical data analysis. The data are presented as the mean \pm SEM. The statistical significance of differences between the groups was assessed by one- or two-way ANOVA, followed by the Bonferroni's/Dunnett's test or Student's $t$ test.
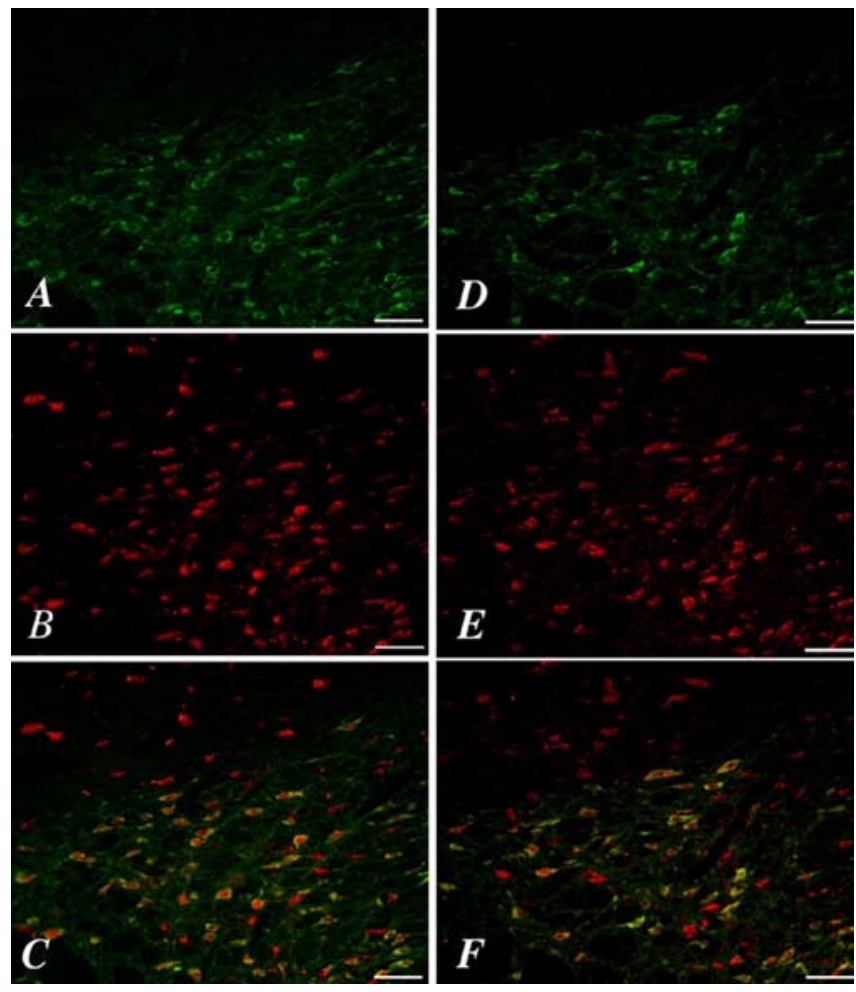

Figure 1. Expression of orexin 1 or orexin 2 receptors in dopamine neurons of the VTA. Immunostaining for TH $(\boldsymbol{A}, \boldsymbol{D})$ is visible in many VTA neurons that show immunoreactivity for orexin 1 receptors $(\boldsymbol{B})$ or orexin 2 receptors $(\boldsymbol{E})$. Colocalization is shown by yellow neurons in the merged images of TH/orexin 1 receptor $(\boldsymbol{C})$ or TH/orexin 2 receptor $(\boldsymbol{F})$. Scale bars, $50 \mu \mathrm{m}$.

\section{Results}

\section{Immunohistochemical approach for the determination of orexin receptors in the VTA}

In the present study, we confirmed the localization of orexin receptor and dopamine neuron in the VTA. Representative images from the VTA are shown in Figure 1. Immunoreactivities (IRs) for the orexin 1 receptor and orexin 2 receptor were observed in the VTA with high density (Fig. $1 B, E$ ). Double-labeling experiments showed that either orexin 1 receptor- or orexin 2 receptor-IR was highly colocalized with the selective dopamine neuron marker TH in the VTA ( $\sim 65 \%$ overlap) (Fig. $1 C, F)$. Orexin receptor IR was strongly detected in the cell surface of TH-positive cells.

\section{Orexin-induced hyperlocomotion and dopamine release}

To further clarify orexin-activated dopamine neurons, mice were treated intracerebroventricularly with orexin A or orexin B. As shown in Figure 2, a single intracerebroventricular injection of orexin A ( 5 and $10 \mathrm{nmol} /$ mouse) produced hyperlocomotion; the mean total activity counts for $120 \mathrm{~min}(277.5 \pm 69.6$ and $353.9 \pm$ 57.5 counts, respectively) were significantly greater than those with saline (Fig. $2 A)(67.0 \pm 17.4$ counts; $p<0.01, p<0.001$ vs saline-treated mice). Similarly, a locomotor-enhancing effect was also seen with a single intracerebroventricular injection of orexin $\mathrm{B}$ at 5 and $10 \mathrm{nmol} /$ mouse (Fig. $2 \mathrm{~B}$ ) (the mean total activity counts for $120 \mathrm{~min}$ were $146.2 \pm 16.5$ and $206.3 \pm 37.9$ counts, respectively, compared with $50.3 \pm 11.2$ counts for saline; $p<$ $0.01, p<0.001$ vs saline-treated mice). These effects were abolished by subcutaneous preinjection of the dopamine receptor antagonist haloperidol $(0.1 \mathrm{mg} / \mathrm{kg})$ [ $107.9 \pm 24.8$ counts per 120 min, $p<0.01$ vs orexin A 10 nmol-treated mice (Fig. 2 A); $89.4 \pm$ 


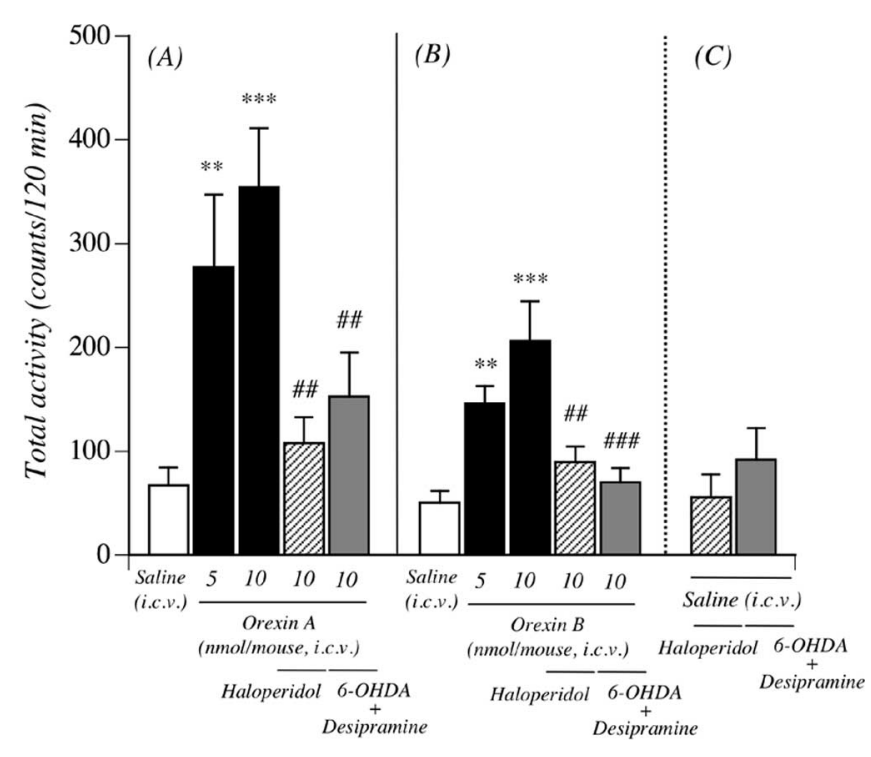

Figure 2. Involvement of central orexinergic system in activation of the mesolimbic dopamine neuron. Orexin $A(\boldsymbol{A})$ and orexin $B(\boldsymbol{B})$ each induced hyperlocomotion in mice. Pretreatment with haloperidol $(0.1 \mathrm{mg} / \mathrm{kg}$, s.c.) or 6-0HDA (150 nmol/mouse, i.c.v.) in combination with desipramine $(25 \mathrm{mg} / \mathrm{kg}$, s.c.) blocked the effects of orexins. C, Total locomotor activity induced by saline pretreatment with haloperidol or 6-OHDA in combination with desipramine. Each column represents the mean total activity for 120 min with SEM of $8-17$ mice. ${ }^{* *} p<0.01$ ${ }^{* * *} p<0.001$ versus saline-treated mice. ${ }^{\# \#} p<0.01,{ }^{\# \# \#} p<0.001$ versus orexin $A$ - or orexin B-treated mice.

Table 1. Decrease in dopamine content in the limbic forebrain from desipramine6-0HDA-treated mice

\begin{tabular}{lc}
\hline Treatment & Dopamine $(\mathrm{ng} / \mathrm{g}$ wet tissue) \\
\hline Saline-vehicle & $11,784.2 \pm 106.5$ \\
Desipramine-6-OHDA & $8098.8 \pm 27.3^{*}$ \\
\hline
\end{tabular}

Each value represents the mean \pm SEM. Mice were killed 72 hours after intracerebroventricular injection of vehicle or 6-OHDA. The statistical significance of differences between groups was assessed with Student's $t$ test. ${ }^{*} p<0.001$ versus saline-treated group.

15.0 counts per $120 \mathrm{~min}, p<0.01$ vs orexin B 10 nmol-treated mice (Fig. $2 B$ )]. In addition, pretreatment with the intracerebroventricular administration of 6-OHDA in combination with the subcutaneous administration of desipramine markedly suppressed the hyperlocomotion induced by the intracerebroventricular administration of orexins (152.9 \pm 42.1 counts per 120 min, $p<0.01$ vs orexin A $10 \mathrm{nmol}$ (Fig. $2 A$ ); $70.3 \pm 13.9$ counts per 120 min, $p<0.001$ vs orexin B $10 \mathrm{nmol}$ (Fig. 2 B)]. Under these conditions, the total locomotor activity induced by intracerebroventricular saline was not affected by either haloperidol or 6-OHDA in combination with desipramine treatment; the total activity counts for $120 \mathrm{~min}$ were $55.5 \pm 22.1$ for haloperidol and $91.8 \pm 30.5$ for 6 -OHDA in combination with desipramine. Pretreatment with the intracerebroventricular administration of 6-OHDA in combination with the subcutaneous administration of desipramine markedly decreased the basal levels of dopamine in the mouse limbic forebrain (including the NAcc) $(p<0.001 \mathrm{vs}$ intracerebroventricular vehicle in combination with subcutaneous saline) (Table 1). The effects of intra-VTA administration of orexin A or orexin B on the dialysate dopamine level in the NAcc are shown in Figure 3. The dopamine levels were markedly increased by the injection of orexin A or orexin B compared with saline treatment (orexin A, $F_{(1,6)}=37.1, p<0.001$; orexin $\mathrm{B}$, $\left.F_{(1,5)}=282.7, p<0.001\right)$. The injection of orexins into the VTA also produced a significant increase in a major dopamine metab- olite 3,4-dihydroxyphenylacetic acid (DOPAC) (orexin A, $F_{(1,6)}=$ $11.6, p<0.05$; orexin $\left.\mathrm{B}, F_{(1,5)}=10.9, p<0.05\right)$. Similarly, orexins increased the level of another dopamine metabolite, homovanillic acid (HVA) (orexin A, $F_{(1,6)}=14.9, p<0.01$; orexin $\mathrm{B}, F_{(1,5)}=10.2$, $p<0.05)$.

\section{Decrease in prepro-orexin mRNA levels in prepro-orexin knock-out mice and suppression of the morphine-induced rewarding effect and hyperlocomotion in these mice}

To verify whether mutation of the prepro-orexin gene could result in a loss of prepro-orexin mRNA, we isolated total RNA from the whole brain of wild-type and prepro-orexin knock-out mice to perform reverse transcription (RT)-PCR using prepro-orexinspecific primers. Prepro-orexin mRNA was readily identified in the whole brain of wild-type, but not in that of prepro-orexin knock-out, mice (Fig. 4A). We next tried to determine whether lack of the prepro-orexin gene could influence the expression of $\mu$-opioid receptors. This mutation eliminated prepro-orexin with no significant changes in the expression of $\mu$-opioid receptors ( $105.3 \pm 8.9 \%$ of wild-type mice) (data not shown), which confirmed that these mice should be useful for studying the distinct role of orexin. As shown in Figure 4B, in both genotypes, the subcutaneous saline-conditioned group exhibited no preference for either place. The mean conditioning scores were $2.6 \pm 18.7 \mathrm{~s}$ for wild-type mice and $5.5 \pm 32.6 \mathrm{~s}$ for prepro-orexin knock-out mice. The subcutaneous administration of morphine produced a dose-dependent preference for the drug-associated place in wildtype mice; the mean conditioning scores were $47.1 \pm 17.6 \mathrm{~s}$ for wild-type mice with $1 \mathrm{mg} / \mathrm{kg}$ morphine, $99.8 \pm 42.3 \mathrm{~s}$ for wildtype mice with $3 \mathrm{mg} / \mathrm{kg}$ morphine, $173.7 \pm 32.8 \mathrm{~s}$ for wild-type mice with $5 \mathrm{mg} / \mathrm{kg}$ morphine ( $p<0.01$ vs wild-type and salineconditioned group), and $181.4 \pm 21.8 \mathrm{~s}$ for wild-type mice with $10 \mathrm{mg} / \mathrm{kg}$ morphine $(p<0.01$ vs wild-type and salineconditioned group). However, the morphine $(3,5$, or $10 \mathrm{mg} / \mathrm{kg}$, s.c.)-induced place preference was abolished in prepro-orexin knock-out mice; the mean conditioning scores were $-11.4 \pm$ $34.0 \mathrm{~s}$ for prepro-orexin knock-out mice with $3 \mathrm{mg} / \mathrm{kg}$ morphine ( $p<0.05$ vs wild-type and $3 \mathrm{mg} / \mathrm{kg}$ morphine-conditioned group), $-20.0 \pm 25.2 \mathrm{~s}$ for prepro-orexin knock-out mice with 5 $\mathrm{mg} / \mathrm{kg}$ morphine $(p<0.001$ vs wild-type and $5 \mathrm{mg} / \mathrm{kg}$ morphine-conditioned group), and $46.8 \pm 72.3 \mathrm{~s}$ for preproorexin knock-out mice with $10 \mathrm{mg} / \mathrm{kg}$ morphine $(p<0.05$ vs wild-type and $10 \mathrm{mg} / \mathrm{kg}$ morphine-conditioned group). For all of the doses of morphine used in the present study $(1-10 \mathrm{mg} / \mathrm{kg})$, a significant place preference was not observed in mice that lacked the prepro-orexin gene. Under these conditions, there was no difference of a significant conditioned place aversion induced by lithium chloride between the two genotypes; the mean conditioning scores were $-108.1 \pm 20.9 \mathrm{~s}$ for wild-type mice with $20 \mathrm{mg} / \mathrm{kg}$ lithium chloride ( $p<0.05$ vs wild-type and saline-conditioned group) and $-99.3 \pm 50.4 \mathrm{~s}$ for prepro-orexin knock-out mice with $20 \mathrm{mg} / \mathrm{kg}$ lithium chloride $(p<0.05$ vs prepro-orexin knock-out and saline-conditioned group). Figure 5, $A$ and $B$, shows morphine-induced hyperlocomotion in wild-type mice and prepro-orexin knock-out mice. After habituation, morphine (5 and $10 \mathrm{mg} / \mathrm{kg}$, s.c.) produced a significant increase in locomotion in wild-type mice; the mean total activity counts for $180 \mathrm{~min}$ were $1297.8 \pm 141.2$ and $2866.4 \pm 242.5$ counts, respectively (Fig. $5 B$ ). In contrast, morphine ( 5 and $10 \mathrm{mg} / \mathrm{kg}$, s.c.)-induced hyperlocomotion was significantly suppressed in prepro-orexin knock-out mice; the mean total activity counts for 180 min were $491.4 \pm 126.2$ and $1460.2 \pm 285.8$ counts $(p<0.001$ vs wild-type mice) (Fig. $5 B$ ). After habituation, saline treatment produced no 
differences in locomotion between wildtype and prepro-orexin knock-out mice; the mean total activity counts for $180 \mathrm{~min}$ were $108.4 \pm 23.5$ and $76.9 \pm 16.1$ counts, respectively (Fig. 5B).

Suppression of the rewarding effect of morphine by intra-VTA injection of the selective orexin receptor antagonist Figure $6 \mathrm{~A}$ shows the placement of microinjection cannulas within the rat VTA or SN. Guide cannulas were localized above the VTA or SN. Only data from rats in which guide cannulas had been accurately inserted in the VTA or SN were used for subsequent statistical analysis. The diffusion of the microinjection with $0.3 \mu \mathrm{l}$ volume was strictly observed inside the VTA or SN area. An intra-VTA microinjection with vehicle produced no preference for either place; the mean conditioning score was $8.4 \pm 15.5 \mathrm{~s}$ (Fig. $6 \mathrm{~B}$ ). The selective orexin receptor antagonist SB334867A alone did not induce either significant place preference or place aversion in rats; the mean conditioning score was $7.4 \pm 18.1 \mathrm{~s}$ for SB334867A (10 nmol). Under these conditions, the place preference induced by morphine $(8 \mathrm{mg} / \mathrm{kg}$, i.p., $170.3 \pm$ 22.4 s; $p<0.001$ vs vehicle-pretreated and saline-conditioned group) was significantly and dose dependently suppressed by intra-VTA injection of the SB334867A $(83.1 \pm 24.3 \mathrm{~s} ; p<0.0110$ nmol SB334867A-pretreated and morphine-conditioned group vs vehicle-pretreated and morphine-conditioned group). However, the inhibition was not observed by intra-SN injection of the SB334867A.

Changes in the increased dialysate dopamine level induced by morphine in prepro-orexin knock-out mice

Figure $7 A$ shows the placement of microdialysis probes within the mouse NAcc. Probe-inserted regions were localized in the NAcc. Only data from mice in which probes had been accurately inserted in the NAcc were used for subsequent statistical analysis. In the microdialysis study, there was no difference in the basal level of dopamine in the NAcc between the two genotypes (wild-type mice, $2.68 \pm 0.18 \mathrm{nM}$; prepro-orexin knock-out mice, $2.37 \pm 0.21$ $\mathrm{nm}$ ) (Table 2). The effects of subcutaneous administration of morphine on the dialysate dopamine level in the mouse NAcc are shown in Figure $7 B$. The dopamine levels were markedly increased by subcutaneous injection of morphine at $10 \mathrm{mg} / \mathrm{kg}$ compared with that induced by saline treatment in both genotypes. Under these conditions, the increased level of dialysate dopamine in the NAcc stimulated by morphine was significantly decreased by deletion of the prepro-orexin gene $\left(F_{(1,11)}=5.25 ; p<0.05\right.$ wild-type mice treated with morphine vs prepro-orexin knockout mice treated with morphine) (Fig. $7 B$ ).

\section{Discussion}

It has been proposed recently that orexins are involved in the mechanisms of emotionality (de Lecea et al., 1998; Sakurai et al., 1998; Hagan et al., 1999). The activation of mesolimbic dopamine neurons in the VTA is likely to be involved in this process (Wise and Rompre, 1989; Wilson et al., 1995; Berridge, 1996; Berridge and Robinson, 1998; Narita et al., 2001a). As previously reported, orexin-like IR is essentially restricted to the $\mathrm{LH}$ region (de Lecea et al., 1998; Peyron et al., 1998; Date et al., 1999). This orexin $\mathrm{B}, F_{(1,5)}=10.2, p<0.05$

Figure 3. Effects of orexin administration into the VTA on the dialysate dopamine level in the NAcc. After the collection of dopamine. Data are expressed as percentages of the corresponding baseline levels with $S E M$ for three to five rats. Dopamine, saline $11.6, p<0.05$; saline versus orexin $B, F_{(1,5)}=10.9, p<0.05$. HVA, saline versus orexin $A, F_{(1,6)}=14.9, p<0.01$; saline versus

(B) O Saline-dopamine Orexin B $(1$ nmol $)$-dopamine

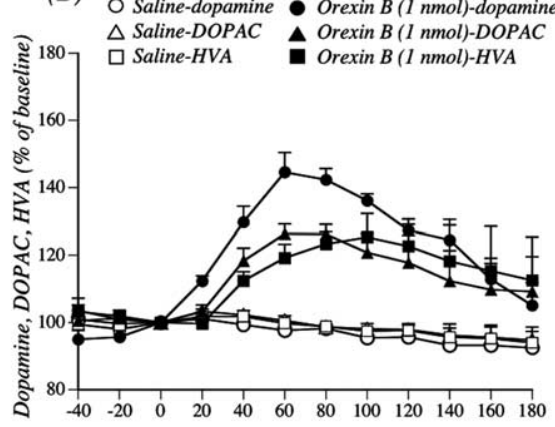

Time after the orexin B treatment

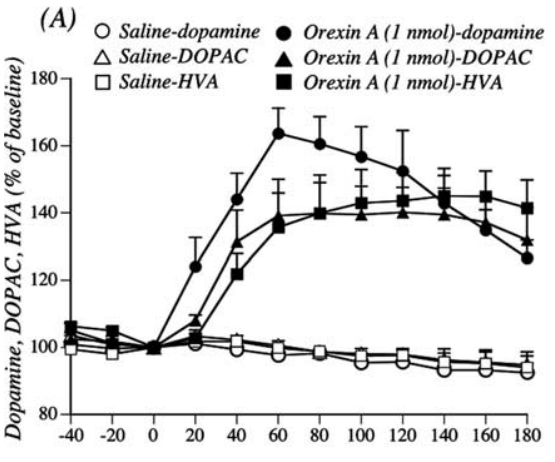




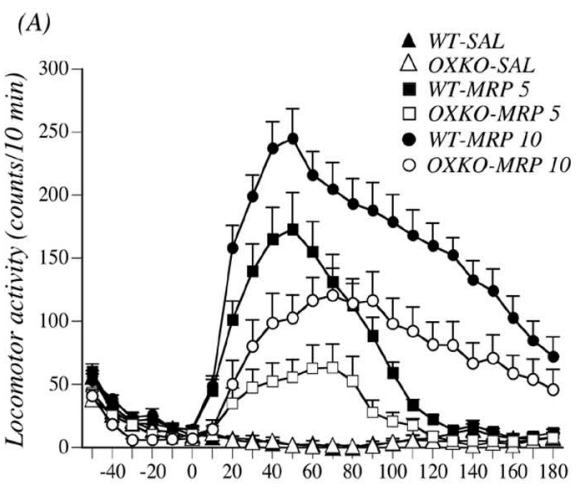

Time after administration ( $\mathrm{min}$ )
(B)

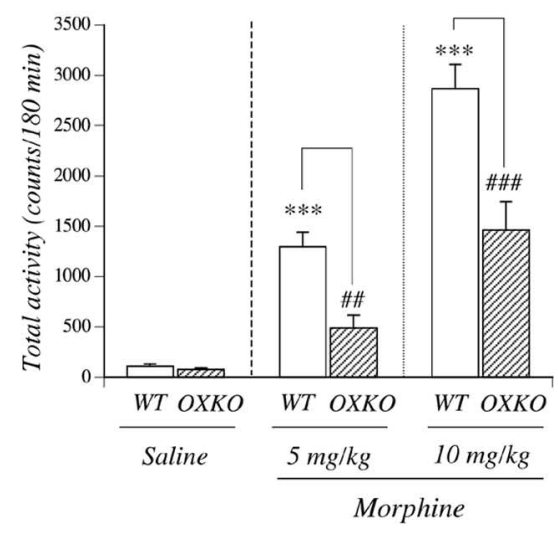

area is also the region in which Fadel and Deutch (2002) observed the greatest number of retrogradely labeled cells after FluoroGold deposition in the VTA. As observed previously in the rat brain (Hervieu et al., 2001; Marcus et al., 2001), we found here that functional orexin receptors, including orexin 1 and orexin 2 receptors, were expressed at the surface of $\mathrm{TH}$ positive dopamine neurons in the mouse VTA. Furthermore, we reported previously that orexin A increases the intracellular $\mathrm{Ca}^{2+}$ concentration in rat VTA dopamine neurons via phosphatidylcholine-specific phospholipase C (PLC) (Uramura et al., 2001). We found using primary neuronal cell cultures obtained from newborn mice that the activation of orexin receptors induced by either orexin A or orexin B produced a robust increase in the intracellular $\mathrm{Ca}^{2+}$ concentration through G-proteins in the mouse dopamine neuron (data not shown). As reported previously using rats (Nakamura et

(A)

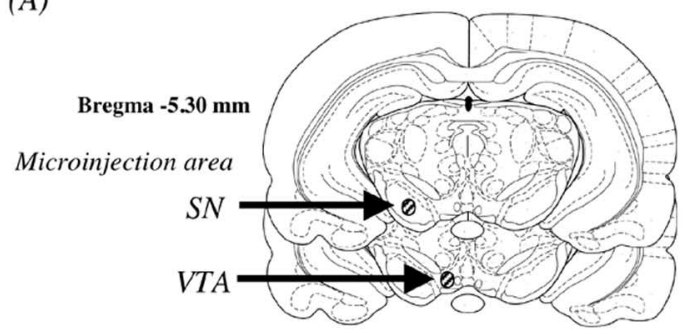

(B)
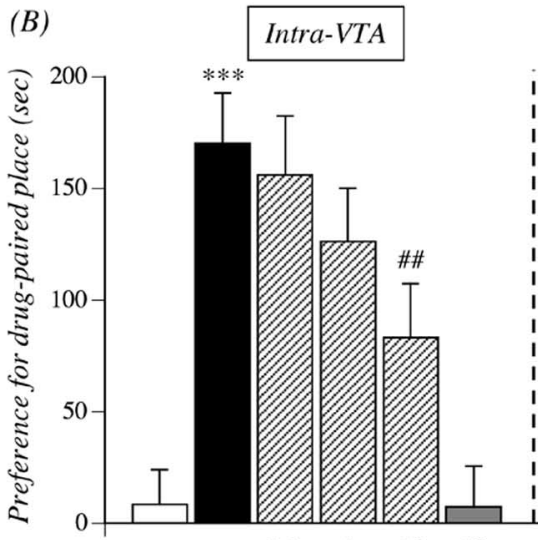

$\begin{array}{llll}0.1 & 1 & 10 & 10\end{array}$

Pre-treatment drug Vehicle SB334867A (nmol/rat)

Conditioning drug (i.p.)

Figure 6. Suppression of the rewarding effect of morphine by intra-VTA injection of the selective orexin receptor antagonist. $\boldsymbol{A}$, Localization of microinjection sites in the rat VTA and SN. Stippled lines show the region in the rat brain in which a cannula was inserted. $\boldsymbol{B}$, Effect of the microinjection of the selective orexin receptor antagonist SB334867A into the VTA or SN on the morphine-induced place preference. Ordinate, Preference for drug-paired place, as defined by the postconditioning test score minus preconditioning test score in the drug treatment side. Rats were microinjected with SB334867A 10 min before the start of conditioning with morphine. The data represent the mean \pm SEM of five to eight rats. ${ }^{* * *} p<0.001$ versus vehiclepretreated and saline-conditioned rats; ${ }^{\# \#} p<0.01$ versus vehicle-pretreated and morphineconditioned rats. al., 2000), either orexin A or orexin B given intracerebroventricularly caused a significant increase in haloperidol-sensitive locomotion in mice. It should be mentioned that the depletion of dopamine in the mouse brain significantly suppressed the hyperlocomotion induced by either orexin A or orexin B. In addition, we demonstrated here that the levels of dopamine and its major metabolite in the NAcc were markedly increased by the microinjection of orexins into the VTA. These results strongly support the idea that activation of the orexin-containing neuron in the VTA leads to the direct activation of mesolimbic dopamine neurons at the somatodendritic level.

An electrophysiological study demonstrated that the systemic administration of morphine elicits an increase in the firing rate of dopaminergic neurons in the VTA (Matthews and German, 1984). Using the conditioned place preference paradigm, intraVTA administration of either the selective $\mu$-opioid receptor agonist $\left[\mathrm{D}-\mathrm{Ala}^{2}, \mathrm{~N}-\mathrm{MePhe}^{4}, \mathrm{Gly}^{-\mathrm{ol}^{5}}{ }^{5}\right.$ enkephalin (DAMGO) or the prototypical $\mu$-opioid receptor agonist morphine has been shown to produce a rewarding effect (Bals-Kubik et al., 1993; Narita et al., 2001a). Both the DAMGO- and morphine-induced place preference can be blocked by dopamine receptor antagonists (Phillips et al., 1983; Shippenberg and Herz, 1988; Shippenberg et al., 1993). These findings indicate that the dopaminecontaining neurons in the midbrain VTA, which has a high density of $\mu$-opioid receptors, play a critical role in the rewarding effects of $\mu$-opioids. It has been reported that endogenous opioids are needed for orexin-induced feeding (Clegg et al., 2002). It is of interest to note that prepro-orexin knock-out mice develop attenuated morphine-induced physical dependence and withdrawal (Georgescu et al., 2003), suggesting a possible interaction between orexins and opioids. In this study, we demonstrated for the first time that the place preference induced by morphine was significantly suppressed by intra-VTA injection of the selective orexin receptor antagonist, indicating that VTA orexin neurons may be implicated in the morphine-induced rewarding effect.

Knock-out mice with prepro-orexin gene deletions have been successfully developed by homologous recombination (Chemelli et al., 1999). The availability of transgenic prepro-orexin knockout mice allows us to determine the physiological function me- 
(A)

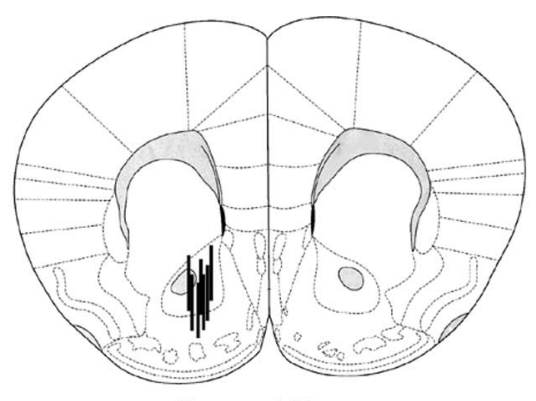

(B)

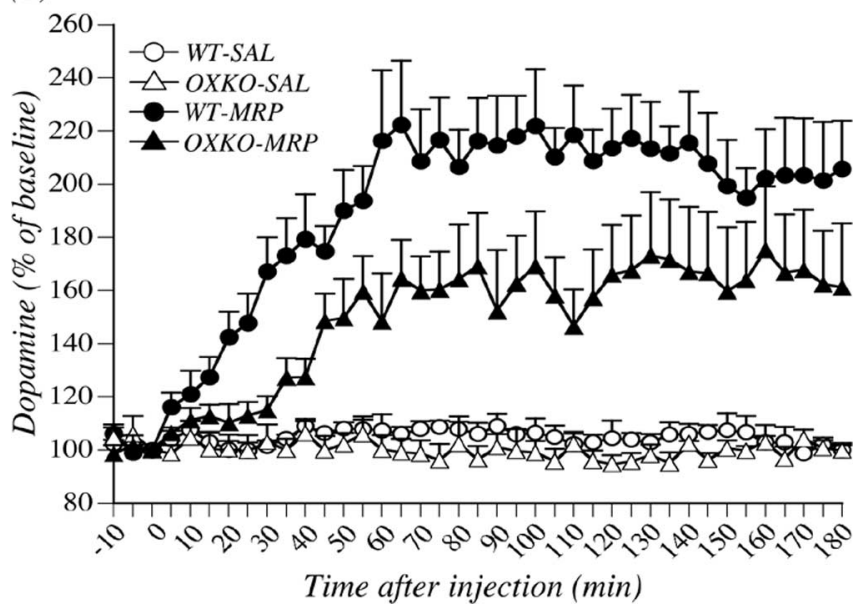

Figure 7. Change in the increased dialysate dopamine level induced by morphine in preproorexin knock-out mice. $\boldsymbol{A}$, Localization of microdialysis probe sites in the mouse NAcc. Stippled lines represent regions in which microdialysis probes were inserted in the mouse brain. $\boldsymbol{B}$, Effects of treatment with morphine (MRP) on the dialysate dopamine level in the NAcc in wild-type (WT) and prepro-orexin knock-out (OXKO) mice. Morphine ( $10 \mathrm{mg} / \mathrm{kg}$, s.c.) or saline $(\mathrm{SAL})$ was injected at time 0 . The data are expressed as percentages of the corresponding baseline levels with SEM of four to seven mice. $F_{(1,11)}=5.25, p<0.05$ wild-type mice treated with morphine versus prepro-orexin knock-out mice treated with morphine.

Table 2. Basal dialysate levels of dopamine in the nucleus accumbens in wild-type prepro-orexin knock-out mice

\begin{tabular}{ll}
\hline Genotype & Dopamine (nм) \\
\hline Wild-type mice & $2.68 \pm 0.18$ \\
Prepro-orexin knock-out mice & $2.73 \pm 0.21$ \\
\hline
\end{tabular}

The data represent the mean \pm SEM of eight to nine mice. The statistical significance of differences between groups was assessed with Student's $t$ test.

diated via central orexin neurons and the direct interaction between the $\mu$-opioidergic and orexinergic systems. In the present study using prepro-orexin-knock-out mice, we confirmed that the deletion of orexin had no effect on the expression of $\mu$-opioid receptors, which suggests that deletion of the prepro-orexin gene may not directly affect $\mu$-opioidergic function in the brain and demonstrates that these mice are useful for studying the distinct role of the orexinergic system. Using mice that lacked the preproorexin gene, we investigated the rewarding effect of morphine. Morphine produced a significant dose-dependent place preference for the drug-associated place in wild-type mice, whereas no preferences were seen in prepro-orexin knock-out mice that had been treated with morphine at $1-10 \mathrm{mg} / \mathrm{kg}$. Under these conditions, there was no difference of a significant conditioned place aversion induced by lithium chloride between the two genotypes. Together, the present findings provide evidence that the excitation of brain orexin neurons and/or the tonic activation of orexin receptors is specifically required for the rewarding effect of $\mu$-opioid receptor agonists.

In the present study, we also found that deletion of the preproorexin gene was associated with an almost complete failure to induce hyperlocomotion and increased level of dialysate dopamine in the NAcc after treatment with morphine. Although the exact neuronal mechanism is unclear at this time, these findings suggest that activation of the mesolimbic dopamine system by the $\mu$-opioid receptor agonist morphine may be directly or indirectly regulated by the central orexinergic system. As generally accepted, most $\mu$-opioid receptors in the VTA are expressed on GABA interneurons. Although the activation of mesolimbic dopamine neurons caused by morphine is considered to occur mainly by inhibiting GABA interneuron activity via the activation of $\mu$-opioid receptors, it is possible that the morphineinduced activation of mesolimbic dopamine neurons is, at least in part, regulated directly by the activation of orexin neurons via $\mu$-opioid receptor-mediated excitation signal transmission. This contention is supported by our recent finding that morphine activates the PLC/inositol 1, 4, 5-triphosphate pathway through $\mu$-opioid receptors (Aoki et al., 2003; Narita et al., 2003). Another possibility is that rewarding effect, hyperlocomotion, and dopamine release in the NAcc after treatment with morphine may be, at least in part, regulated by the activated mesolimbic dopaminergic system via the activation of $\mu$-opioid receptors on the orexin neuron in the $\mathrm{LH}$, which directly terminates to the VTA. In fact, $\mu$-opioid receptors are highly detected in the LH (Mansour et al., 1987; Delfs et al., 1994; Mansour et al., 1994; Briski and Sylvester, 2001). It should be also mentioned that a subset $(\sim 50 \%)$ of orexin neurons expresses $\mu$-opioid receptors, and that most of these cells respond to morphine by induction of cAMP response element activity or $c$-fos (Georgescu et al., 2003).

In conclusion, we report here for the first time that the activation of orexin neurons in the VTA is directly implicated in the rewarding effect and hyperlocomotion induced by morphine, which is associated with activation of the mesolimbic dopamine pathway in the rodent.

\section{References}

Alhaider AA (1991) Antinociceptive effect of ketanserin in mice: involvement of supraspinal $5-\mathrm{HT}_{2}$ receptors in nociceptive transmission. Brain Res 543:335-340.

Aoki T, Narita M, Ohnishi O, Mizuo K, Narita M, Yajima Y, Suzuki T (2003) Disruption of the type 1 inositol 1,4,5-trisphosphate receptor gene suppresses the morphine-induced antinociception in the mouse. Neurosci Lett 350:69-72.

Bals-Kubik R, Ableitner A, Herz A, Shippenberg TS (1993) Neuroanatomical sites mediating the motivational effects of opioids as mapped by the conditioned place preference paradigm in rats. J Pharmacol Exp Ther 264:489-495.

Berridge KC (1996) Food reward: brain substrates of wanting and liking. Neurosci Biobehav Rev 20:1-25.

Berridge KC, Robinson TE (1998) What is the role of dopamine in reward: hedonic impact, reward learning, or incentive salience? Brain Res Rev 28:309-369.

Briski KP, Sylvester PW (2001) Co-distribution of Fos- and $\mu$ opioid receptor immunoreactivity within the rat septopreoptic area and hypothalamus during acute glucose deprivation: effects of the $\mu$ receptor antagonist CTOP. Neurosci Lett 306:141-144.

Chemelli RM, Willie JT, Sinton CM, Elmquist JK, Scammell T, Lee C, Richardson JA, Williams SC, Xiong Y, Kisanuki Y, Fitch TE, Nakazato M, Hammer RE, Saper CB, Yanagisawa M (1999) Narcolepsy in orexin knockout mice: molecular genetics of sleep regulation. Cell 98:437-451.

Clegg DJ, Air EL, Woods SC, Seeley RJ (2002) Eating elicited by orexin-A, but not melanin-concentrating hormone, is opioid mediated. Endocrinology 143:2995-3000.

Date Y, Ueta Y, Yamashita H, Yamaguchi H, Matsukura S, Kangawa K, Saku- 
rai T, Yanagisawa M, Nakazato M (1999) Orexins, orexigenic hypothalamic peptides, interact with autonomic, neuroendocrine and neuroregulatory systems. Proc Natl Acad Sci USA 96:748-753.

de Lecea L, Kilduff TS, Peyron C, Gao X, Foye PE, Danielson PE, Fukuhara C, Battenberg EL, Gautvik VT, Bartlett II FS, Frankel WN, van den Pol AN, Bloom FE, Gautvik KM, Sutcliffe JG (1998) The hypocretins: hypothalamus-specific peptides with neuroexcitatory activity. Proc Natl Acad Sci USA 95:322-327.

Delfs JM, Kong H, Mestek A, Chen Y, Yu L, Reisine T, Chesselet MF (1994) Expression of $\mu$ opioid receptor mRNA in rat brain: an in situ hybridization study at the single cell level. J Comp Neurol 345:46-68.

Fadel J, Deutch AY (2002) Anatomical substrates of orexin-dopamine interaction: lateral hypothalamic projections to the ventral tegmental area. Neuroscience 111:379-387.

Georgescu D, Zachariou V, Barrot M, Mieda M, Willie JT, Eisch AJ, Yanagisawa M, Nestler EJ, DiLeone RJ (2003) Involvement of the lateral hypothalamic peptide orexin in morphine dependence and withdrawal. J Neurosci 23:3106-3111.

Hagan JJ, Leslie RA, Patel S, Evans ML, Wattam TA, Holmes S, Benham CD, Taylor SG, Routledge C, Hemmati P, Munton RP, Ashmeade TE, Shah AS, Hatcher JP, Hatcher PD, Jones DN, Smith MI, Piper DC, Hunter AJ, Porter RA, Upton N (1999) Orexin A activates locus coeruleus cell firing and increases arousal in the rat. Proc Natl Acad Sci USA 96:10911-10916.

Haley MJ, McCormick WG (1957) Pharmacological effects produced by intracerebral injections of drugs in the conscious mouse. $\mathrm{Br} \mathrm{J}$ Pharmacol $12: 12-15$.

Hervieu GJ, Cluderay JE, Harrison DC, Roberts JC, Leslie RA (2001) Gene expression and protein distribution of the orexin-1 receptor in the rat brain and spinal cord. Neuroscience 103:777-797.

Koob GF (1992) Drugs of abuse: anatomy, pharmacology and function of reward pathways. Trends Pharmacol Sci 13:177-184.

Korotkova TM, Sergeeva OA, Eriksson KS, Haas HL, Brown RE (2003) Excitation of ventral tegmental area dopaminergic and nondopaminergic neurons by orexins/hypocretins. J Neurosci 23:7-11.

Mansour A, Khachaturian H, Lewis ME, Akil H, Watson SJ (1987) Autoradiographic differentiation of $\mu, \delta$, and $\kappa$ opioid receptors in the rat forebrain and midbrain. J Neurosci 7:2445-2464.

Mansour A, Fox CA, Thompson RC, Akil H, Watson SJ (1994) $\mu$-Opioid receptor mRNA expression in the rat CNS: comparison to $\mu$-receptor binding. Brain Res 643:245-265.

Marcus JN, Aschkenasi CJ, Lee CE, Chemelli RM, Saper CB, Yanagisawa M, Elmquist JK (2001) Differential expression of orexin receptors 1 and 2 in the rat brain. J Comp Neurol 435:6-25.

Matthews RT, German DC (1984) Electrophysiological evidence for the excitation of rat ventral tegmental area dopamine neurons by morphine. Neuroscience 3:617-625.

Nakamura T, Uramura K, Nambu T, Yada T, Goto K, Yanagisawa M, Sakurai $\mathrm{T}$ (2000) Orexin-induced hyperlocomotion and stereotypy are mediated by the dopaminergic system. Brain Res 873:181-187.

Narita M, Suzuki T, Funada M, Misawa M, Nagase H (1993) Involvement of $\delta$-opioid receptors in the effects of morphine on locomotor activity and the mesolimbic dopaminergic system in mice. Psychopharmacology 111: 423-426.

Narita M, Funada M, Suzuki T (2001a) Regulations of opioid dependence by opioid receptor types. Pharmacol Ther 89:1-15.

Narita M, Mizoguchi H, Suzuki T, Narita M, Dun NJ, Imai S, Yajima Y, Nagase H, Suzuki T, Tseng LF (2001b) Enhanced $\mu$-opioid responses in the spinal cord of mice lacking protein kinase $\mathrm{C} \gamma$ isoform. J Biol Chem 276:15409-15414.

Narita M, Mizuo K, Shibasaki M, Narita M, Suzuki T (2002) Up-regulation of the $\mathrm{G}_{\mathrm{q} / 11 \alpha}$ protein and protein kinase $\mathrm{C}$ during the development of sensitization to morphine-induced hyperlocomotion. Neuroscience 111:127-132.

Narita M, Ohnishi O, Narita M, Aoki T, Suzuki M, Yajima Y, Funahashi H, Shioda S, Suzuki T (2003) Direct evidence for the activation of phospholipase $\mathrm{C} \gamma 1$ by in vivo treatment with morphine in the mouse periaqueductal gray matter. Brain Res 970:140-148.

Paxinos G, Franklin KBJ (1997) The mouse brain in stereotaxic coordinates. San Diego: Academic.

Paxinos G, Watson C (1998) The rat brain in stereotaxic coordinates. New York: Academic.

Peyron C, Tighe DK, van den Pol AN, de Lecea L, Heller HC, Sutcliffe JG, Kilduff TS (1998) Neurons containing hypocretin (orexin) project to multiple neuronal systems. J Neurosci 18:9996-10015.

Phillips AG, LePiane FG, Fibiger HG (1983) Dopaminergic mediation of reward produced by direct injection of enkephalin into the ventral tegmental area of rat. Life Sci 33:2505-2511.

Sakurai T, Amemiya A, Ishii M, Matsuzaki I, Chemelli RM, Tanaka H, Williams SC, Richardson JA, Kozlowski GP, Wilson S, Arch JR, Buckingham RE, Haynes AC, Carr SA, Annan RS, McNulty DE, Liu WS, Terrett JA, Elshourbagy NA, Bergsma DJ, Yanagisawa M (1998) Orexins and orexin receptors: a family of hypothalamic neuropeptides and G proteincoupled receptors that regulate feeding behavior. Cell 92:573-585.

Shippenberg TS, Herz A (1988) Motivational effects of opioids: influence of D-1 versus D-2 receptor antagonists. Eur J Pharmacol 151:233-242.

Shippenberg TS, Bals-Kubik R, Herz A (1993) Examination of the neurochemical substrates mediating the motivational effects of opioid: role of the mesolimbic dopamine system and D-1 vs. D-2 dopamine receptors. J Pharmacol Exp Ther 265:53-59.

Suzuki T, Masukawa Y, Misawa M (1990) Drug interactions in the reinforcing effects of over-the-counter cough syrups. Psychopharmacology 102:438-442.

Uramura K, Funahashi H, Muroya S, Shioda S, Takigawa M, Yada T (2001) Orexin-A activates phospholipase C- and protein kinase C-mediated $\mathrm{Ca}^{2+}$ signaling in dopamine neurons of the ventral tegmental area. NeuroReport 12:1885-1889.

van den Pol AN (1999) Hypothalamic hypocretin (orexin): robust innervation of the spinal cord. J Neurosci 19:3171-3182.

Wilson C, Nomikos GG, Collu M, Fibiger HC (1995) Dopaminergic correlates of motivated behavior: importance of drive. J Neurosci 15:5169-5178

Wise RA, Rompre PP (1989) Brain dopamine and reward. Annu Rev Psychol 40:191-225. 